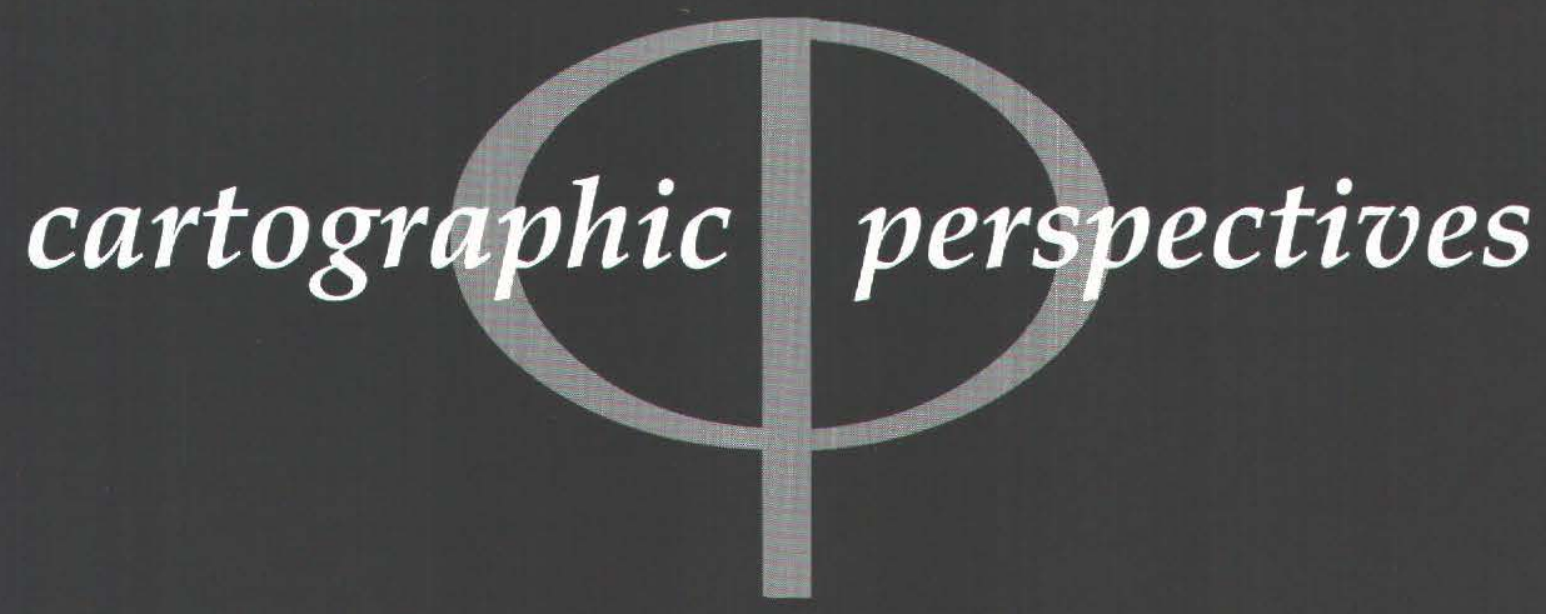

Number 29, Winter 1998

\section{in this issue}

ESSAY

That Interactive Thing You Do

Michael P. Peterson

\section{FEATURED ARTICLES}

Beyond Graduated Circles: Varied Point Symbols for

Representing Quantitative Data on Maps

Cynthia A. Brewer and Andrew J. Campbell

Animation-Based Map Design: The Visual Effects of

Interpolation on the Appearance of Three-Dimensional Surfaces Stephen Lavin, Sonja Rossum, and Shawn R. Slade

Decision-Making with Conflicting Cartographic Information:

The Case of Groundwater Vulnerability Maps

Charles P. Rader and James D. Janke

\section{REVIEWS}

The Dartmouth Atlas of Health Care

Russell S. Kirby

Mapping an Empire: The Geographical Construction of British India, 1765-1843

W. Elizabeth Jepson

Atlas of Oregon Wildlife: Distribution, Habitat, and Natural History

James E. Meacham

CARTOGRAPHIC TECHNIQUES

MAP LIBRARY BULLETIN BOARD

\section{messages}

\section{MESSAGE FROM NACIS' PRESIDENT}

It is a pleasure to serve as the 1997 98 president of NACIS. No, really, I am serious! (as Dave Barry would say). After well over a decade of association with the organization, serving now and then as a member of the board of directors or the $C P$ editorial board, I finally have the pleasure of serving as NACIS' vice president and now president. The words "pleasure" and "president" are seldom found together in the same sentence; let me tell you why I use them together.

For one thing, I get to deliver some good news to NACIS members and others with links to cartography: we have a new editor for Cartographic Perspectives. After a two-year search and several guest editors, we found our new editor, Dr. Michael Peterson of the University of Nebraska-Omaha, right at the head of our own editorial

(continued on page 61)

NEW NACIS WEB SITE www.nacis.org 